\section{A case of severe corrosive esophagitis, gastritis, and liver necrosis caused by ingestion of methyl ethyl ketone peroxide}

\author{
Jung Oh Chang, Jeong Woo Choi, Yong Hwang \\ Department of Emergency Medicine, Wonkwang University Hospital, Iksan, Korea
}

The plastic hardener methyl ethyl ketone peroxide is unstable peroxide that releases free oxygen radicals. Ingestion of this compound induces widespread liver necrosis, severe metabolic acidosis, corrosive esophagitis and gastritis, that is often fatal. A 49-year-old man unintentionally ingested approximately $100 \mathrm{~mL}$ (55\%) of this compound in solution, which was purchased as plastic hardener. Despite resuscitation, he died about 11 hours after admission. We report a patient with poisoning due to methyl ethyl ketone peroxide who presented with corrosive esophagitis and gastritis, gastrointestinal bleeding, and developed ischemia of the bowel and necrosis of the liver and died of severe metabolic acidosis and multiorgan failure.

Keywords Methylethyl ketone; Corrosive esophagitis; Corrosive gastritis; Hepatic necrosis

\section{Capsule \\ Summary}

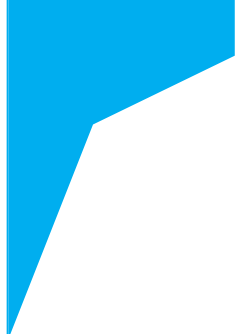

elSSN: 2383-4625

Received: 20 May 2016

Revised: 18 October 2016

Accepted: 3 November 2016

Correspondence to: Jeong Woo Choi Department of Emergency Medicine, Wonkwang University Hospital, 895 Muwang-ro, Iksan 54538, Korea E-mail:dream-02@daum.net

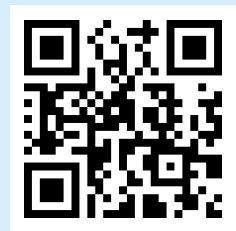

How to cite this article:

Chang JO, Choi JW, Hwang Y. A case of severe corrosive esophagitis, gastritis, and liver necrosis caused by ingestion of methyl ethyl ketone peroxide. Clin Exp Emerg Med 2016;3(4):256-261.

This is an Open Access article distributed under the terms of the Creative Commons Attribution Non-Commercial License (http:// creativecommons.org/licenses/by-nc/3.0/). 


\section{INTRODUCTION}

Methyl ethyl ketone peroxide (MEKP) is a colorless liquid with an acetone-like odor. It is used as a general industrial solvent in the manufacturing of nitrocellulose coating, vinyl film, and smokeless powder. ${ }^{1}$ Despite this widespread use, little information is available regarding what happens to MEKP once it is absorbed by the human body, although it has several physico-chemical properties that may confer toxicity. Even though ingestion of MEKP is rare, it is associated with high morbidity and mortality (Table 1). ${ }^{2-8}$ Herein, we report the fatal poisoning of a 49-year-old man after ingestion of MEKP.

\section{CASE REPORT}

A 49-year-old man inadvertently ingested an estimated 100 milliliters of a solution from a water bottle. The liquid was identified as a plastic hardener that contained 55\% MEKP. The man was brought to the emergency medical center within 30 minutes of ingestion, with shortness of breath, nausea, vomiting, and abdominal discomfort. His medical history was unremarkable.

Upon initial physical examination, the patient was somewhat anxious, but not stridorous; he had a low blood pressure (70/50 $\mathrm{mmHg}$ ), a pulse rate of 84 beats/min, a peripheral oxygen saturation of $99 \%$, and a body temperature of $36.5^{\circ} \mathrm{C}$. No significant abnormal findings were observed upon examination of the chest and abdomen. Laryngoscopy, which was carried out 10 minutes after the patient's arrival in the emergency department, revealed a superficial mucosal injury without edema of the epiglottis, arytenoid, or vocal cords. Furthermore, a chest radiogram and electrocardiogram were performed 30 minutes after his arrival; these were both normal. However, radiography of the abdomen indicated paralytic ileus, and lateral radiography of the neck showed swelling of the arytenoid (Fig. 1).

Initial laboratory blood investigations showed a normal hemo-

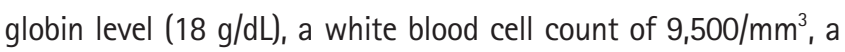
hematocrit of $49.5 \%$, and a platelet count of $139,000 / \mathrm{mm}^{3}$; arterial blood gas analysis ( $\mathrm{ABGA}$ ) revealed a $\mathrm{pH}$ of 7.704 , a $\mathrm{pCO}_{2}$ of $7.4 \mathrm{mmHg}$, a $\mathrm{pO}_{2}$ of $106.3 \mathrm{mmHg}$, and an $\mathrm{HCO}^{3-}$ level of $9.0 \mathrm{mmol} /$ L. A coagulation screen revealed an activated partial thromboplastin time of 56.6 seconds and a prothrombin time of $11.1 \mathrm{sec}-$ onds. Biochemical investigation revealed that blood levels of total bilirubin were $6.96 \mathrm{mg} / \mathrm{dL}$, aspartame aminotransferase were 191 $\mathrm{IU} / \mathrm{L}$, alanine transferase were $108 \mathrm{IU} / \mathrm{L}$, alkaline phosphatase were $762 \mathrm{IU} / \mathrm{L}$, creatinine phosphate kinase were 1,257 IU/L, creatinine phosphate kinase myoglobin were $57 \mathrm{ng} / \mathrm{mL}$, gamma-glutamyl transpeptidase were $523 \mathrm{IU} / \mathrm{L}$, sodium were $133 \mathrm{mEq} / \mathrm{L}$, po- tassium were $3.9 \mathrm{mEq} / \mathrm{L}$, and lactate were $38.8 \mathrm{mg} / \mathrm{dL}$. Blood urea nitrogen and serum creatinine levels were 11.9 and $1.28 \mathrm{mg} / \mathrm{dL}$, respectively. The patient was given $3 \mathrm{~L}$ of normal saline, antibiotics, steroids, hepatotonics, and a high-dose proton pump inhibitor.

Two hours after admission, as he had developed hypotension again, dopamine and norepinephrine were administered, and a central line was inserted; his central venous pressure was $3 \mathrm{~cm}$ $\mathrm{H}_{2} \mathrm{O}$. He had also developed a sore throat and chest discomfort, as well as distention and tenderness in the abdomen.

Contrast computed tomography (CT) of the chest and abdomen was performed three hours after admission; this did not reveal any perforation of a hollow viscus, but showed severe dilatation of the esophagus, severely decreased attenuation of the liver parenchyma, prominent ulcerative changes in the stomach wall that included mucosal disruption and hemorrhagic fluid collection in the stomach cavity, and dilatation of the small bowel associated with air-fluid levels (Fig. 2).

Four hours after admission, the patient had deteriorated into a stuporous mental state; he was experiencing respiratory failure, metabolic acidosis, acute renal failure, and continuous hypotension. For this reason, he was given a large amount of bicarbonate and a vasopressor. ABGA at this time revealed a $\mathrm{pH}$ of 7.21, a $\mathrm{pCO}_{2}$ of $27 \mathrm{mmHg}$, a $\mathrm{pO}_{2}$ of $206 \mathrm{mmHg}$, and an $\mathrm{HCO}^{3-}$ level of $13.4 \mathrm{mmol} / \mathrm{L}$.

Five hours after admission, as his condition had continued to deteriorate, he underwent orotracheal intubation to maintain the airway, and a mechanical ventilator was applied. Follow-up laryngoscopy examination revealed corrosive mucosal injury combined with severe edema of the epiglottis, arytenoids, and vocal cords.

No prominent free air was observed upon CT scanning, although we could not exclude the possibility of bowel perforation. For this reason, we considered exploratory surgery; however, we had to cancel it because the erosive nature of MEKP rendered the necessary scope of the proposed surgery too large. Regardless, the patient's vital signs were worsening rapidly and he was unlikely to have survived surgery. The patient's family agreed to a "do not resuscitate" request.

Seven hours after admission the patient's blood pressure was $60 / 40 \mathrm{mmHg}$, and $\mathrm{ABGA}$ showed a $\mathrm{pH}$ of 7.09 , a pCO $\mathrm{pC}_{2} 25 \mathrm{mmHg}$ a pO $\mathrm{p}_{2}$ of $191 \mathrm{mmHg}$, and an $\mathrm{HCO}^{3-}$ level of $9.0 \mathrm{mmol} / \mathrm{L}$.

Nine hours after admission, he was in a comatose state and showed pulseless hypotension. Ten hours after admission, the patient died of multi-organ failure before the site and extent of damage to the gastrointestinal tract could be determined and corrective surgery performed. 
Table 1. Cases of MEKP ingestion with fatal outcome (death)

\begin{tabular}{|c|c|c|c|c|c|c|c|}
\hline $\begin{array}{c}\text { Author (year of } \\
\text { publication) }\end{array}$ & $\begin{array}{l}\text { Age } \\
\text { (yr) }\end{array}$ & $\begin{array}{l}\text { Amount in- } \\
\text { gested }(\mathrm{mL})\end{array}$ & $\begin{array}{l}\text { MEKP concen- } \\
\text { tration }(\%)\end{array}$ & $\begin{array}{l}\text { Survival } \\
\text { duration }\end{array}$ & Ingestion & Clinical presentation & Treatment \\
\hline Burger et al. $(1971)^{2}$ & 46 & 50 & 60 & $\begin{array}{l}\text { (More than } \\
24 \mathrm{hr} \text { ) }\end{array}$ & Accidental & $\begin{array}{l}\text { Gastrointestinal bleeding } \\
\text { Pneumonia } \\
\text { Sepsis } \\
\text { Renal failure } \\
\text { Hepatic failure }\end{array}$ & $\begin{array}{l}\text { Gastric lavage } \\
\text { Transfusion } \\
\text { Antacids } \\
\text { Steroids } \\
\text { Antibiotics }\end{array}$ \\
\hline $\begin{array}{l}\text { Mittleman et al. } \\
(1986)^{3}\end{array}$ & 41 & Unknown & 50 & $12 \mathrm{hr}$ & Intentional & $\begin{array}{l}\text { Necrosis of liver, small intestine, and colon } \\
\text { Metabolic acidosis } \\
\text { Gastric perforation }\end{array}$ & $\begin{array}{l}\text { Bicarbonate } \\
\text { Steroids } \\
\text { Mechanical } \\
\text { Ventilation } \\
\text { H2-blocker } \\
\text { Antibiotics } \\
\text { Inotropic agent } \\
\text { Surgery }\end{array}$ \\
\hline $\begin{array}{l}\text { Wojdyla et al. } \\
(1979)^{5}\end{array}$ & 60 & 50 & Unknown & $\begin{array}{l}\text { Several } \\
\text { hours }\end{array}$ & Unknown & $\begin{array}{l}\text { Respiratory distress } \\
\text { Metabolic acidosis } \\
\text { Necrosis of small bowel and colon } \\
\text { Peritonitis } \\
\text { Shock }\end{array}$ & Unknown \\
\hline $\begin{array}{l}\text { Wojdyla et al. } \\
(1979)^{5}\end{array}$ & 45 & Unknown & Unknown & $3 \mathrm{hr}$ & Unknown & $\begin{array}{l}\text { DOA, at postmortem } \\
\text { Discolored esophagus } \\
\text { Hyperemic and edematous stomach, duodenum, } \\
\text { and small bowel } \\
\text { Cerebral edema with subarachnoid hyperemia and } \\
\text { small hemorrhages }\end{array}$ & Unknown \\
\hline $\begin{array}{l}\text { Wojdyla et al. } \\
(1979)^{5}\end{array}$ & 2 & 100 & Unknown & Unknown & Unknown & $\begin{array}{l}\text { Abdominal pain } \\
\text { Gastrointestinal bleeding } \\
\text { Respiratory distress } \\
\text { Abnormal liver function test } \\
\text { Mucous membrane necrosis }\end{array}$ & Unknown \\
\hline Litovitz et al. (1990) & 57 & Unknown & Unknown & Unknown & Intentional & $\begin{array}{l}\text { Metabolic acidosis } \\
\text { Hypotension } \\
\text { Myocardial infarction } \\
\text { Pulmonary edema }\end{array}$ & Unknown \\
\hline Moon et al. $(2010)^{7}$ & 53 & 200 & Unknown & $6 \mathrm{hr}$ & Intentional & $\begin{array}{l}\text { Gastric emphysema } \\
\text { Metabolic acidosis } \\
\text { Abnormal liver function test }\end{array}$ & Unknown \\
\hline $\begin{array}{l}\text { Subbalaxmi et al. } \\
(2010)^{8}\end{array}$ & 32 & Unknown & Unknown & Unknown & Intentional & $\begin{array}{l}\text { Gastrointestinal bleeding } \\
\text { Sepsis } \\
\text { Gangrene of bowel } \\
\text { Metabolic acidosis } \\
\text { Hepatic failure } \\
\text { Renal failure } \\
\text { Peritonitis } \\
\text { Multiple organ failure }\end{array}$ & $\begin{array}{l}\text { Transfusion } \\
\text { Inotropic agent } \\
\text { Proton pump inhibitor }\end{array}$ \\
\hline
\end{tabular}

MEKP, methyl ethyl ketone peroxide; DOA, dead on arrival. 


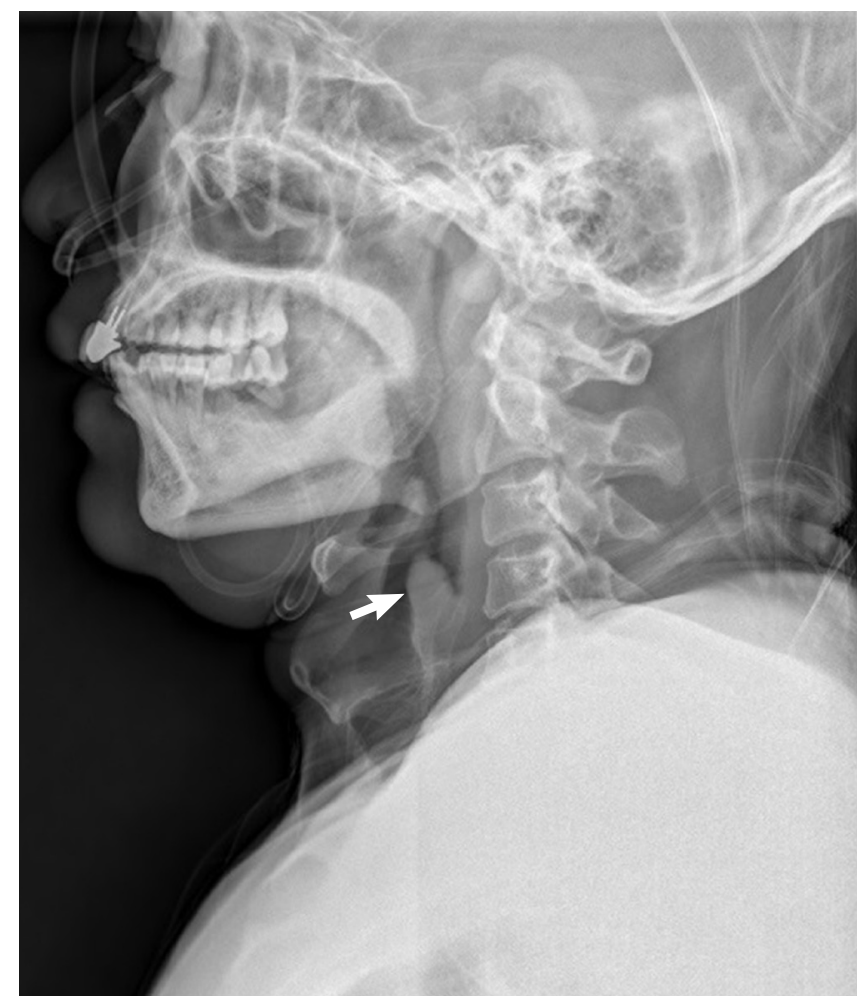

Fig. 1. Swelling of arytenoids was observed on the lateral radiography of the neck (arrow).

\section{DISCUSSION}

It has been postulated that MEKP toxicity is mediated by free radical formation that leads to lipid peroxidation, resulting in corrosive damage to the respiratory and gastrointestinal mucosa, as well as to the liver. Lipid peroxidation is a free radical-initiated chain oxidation of unsaturated lipids. Subcellular membranes are rich in unsaturated fatty acids, and therefore they are a target for lipid peroxidation that results in cellular dysfunction and death. ${ }^{9}$

The toxic dose of MEKP has not been established, but ingestion of any amount should be regarded as serious. Based on data from cases where the dose was known, the toxic oral dose of MEKP has been estimated to be 50 to $100 \mathrm{~mL}$ in adults (Table 1). ${ }^{2-8}$

Studies have shown that, in the acute phase of MEKP intoxication, the clinical spectrum can be subdivided into respiratory complications, gastrointestinal complications, free radical-mediated liver damage, and other secondary acute complications. ${ }^{10}$

Although ingestion of MEKP is rare, it is associated with high morbidity and mortality. ${ }^{7} 10$ To date, 28 cases of MEKP ingestion have been reported, including our case; nine adults and two children have died (Table 1)..$^{2-9}$ Moreover, almost all patients have shown gastrointestinal tract and hepatic injury.

To our knowledge, this case is the second report of MEKP poi- soning in South Korea, and we believe that the chest-abdomen $\mathrm{CT}$ findings were unique in the Korean context. We observed corrosive esophagitis, gastritis, and hepatic necrosis. Our case demonstrates that early gastrointestinal hemorrhage may occur, as may delayed hepatic necrosis, uncontrolled metabolic acidosis, and multi-organ failure. A CT scan is likely more informative than early endoscopy regarding transmural damage to the esophageal and gastric walls, as well as to the extent of necrosis. CT is also more valuable than endoscopy in assessing threatened or existing gastrointestinal perforation, and a CT grading system has been proposed to predict esophageal stricture (Table 2). ${ }^{11} \mathrm{~A}$ recent investigation supported the accuracy of $\mathrm{CT}$ as a diagnostic tool, showing 75\% sensitivity and 90\% specificity in determining injury grade and the need for surgical intervention, as well as in predicting complications such as stricture. ${ }^{12}$ With the advantage of not being invasive, $\mathrm{CT}$ shows promise in the early evaluation of corrosive injury to the gastrointestinal tract, as well as in other organ injuries like hepatic necrosis.

Gastric lavage and emesis are contraindicated after ingestion of corrosive substances because of the risk of trauma or further injury to the upper gastrointestinal tract upon re-exposure; in our case, the $\mathrm{pH}$ of the ingested substance was 4.

Administration of fluids orally should be avoided after MEKP ingestion, because the gastrointestinal tract may have been perforated. In the acute phase, all patients should immediately be evaluated for airway obstruction. Early and repeated endoscopic evaluation of the upper respiratory and gastrointestinal tracts, as well as chest-abdomen $\mathrm{CT}$, is also important. In addition, the electrocardiogram and ABGA, as well as respiratory, renal, and liver functions, should be monitored. Once past the acute phase, patients will require ongoing follow-up to monitor possible late scarring and stricture formation.

Ultimately, no free air was observed in our patient upon chestabdomen $\mathrm{CT}$; this suggests the gastrointestinal tract was not perforated at the time of the scan. However, the CT scan was performed just three hours after admission, so we cannot confirm that the bowel was not perforated during the course of the intoxication. Regardless, we did find prominent ulcerative changes in the stomach wall, combined with mucosal disruption and hemorrhaging in the stomach cavity. We considered explorative surgery at this point, but it was cancelled because the patient's vital signs had been worsening rapidly. Additionally, prednisolone should be given to treat airway edema. ${ }^{13}$

Delayed fibrosis and stricture formation leading to intestinal obstruction are among the main long-term complications of corrosive ingestions. Endoscopic dilatation is required to relieve strictures if present. Furthermore, endoscopic intra-lesional ste- 


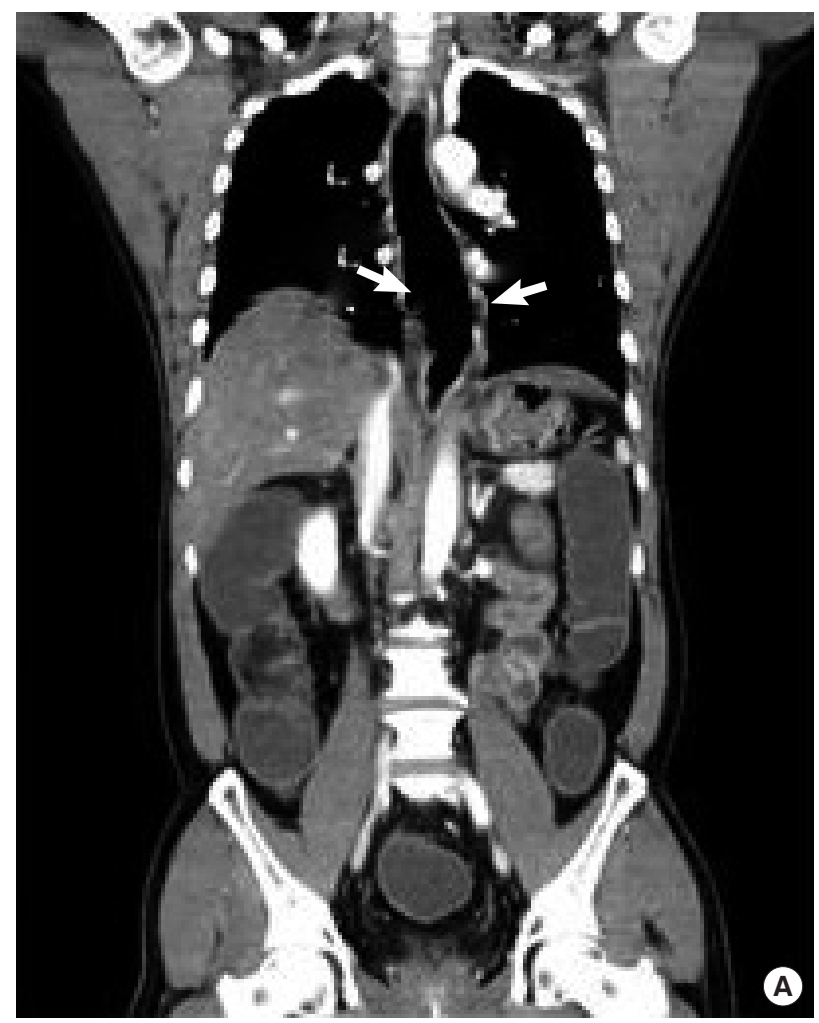

Fig. 2. Abdominal computed tomography image of the esophagus, liver, stomach, and bowel showing (A) severe dilatation of esophagus, which indicates corrosive esophagitis, (B) severe attenuation of liver parenchyma, signifying hepatic necrosis, (C) prominent ulcerative changes to the stomach wall, with mucosal disruption and hemorrhagic fluid collection in the stomach cavity, indicating corrosive gastritis, and (D) small bowel dilatation with air-fluid levels (arrow).
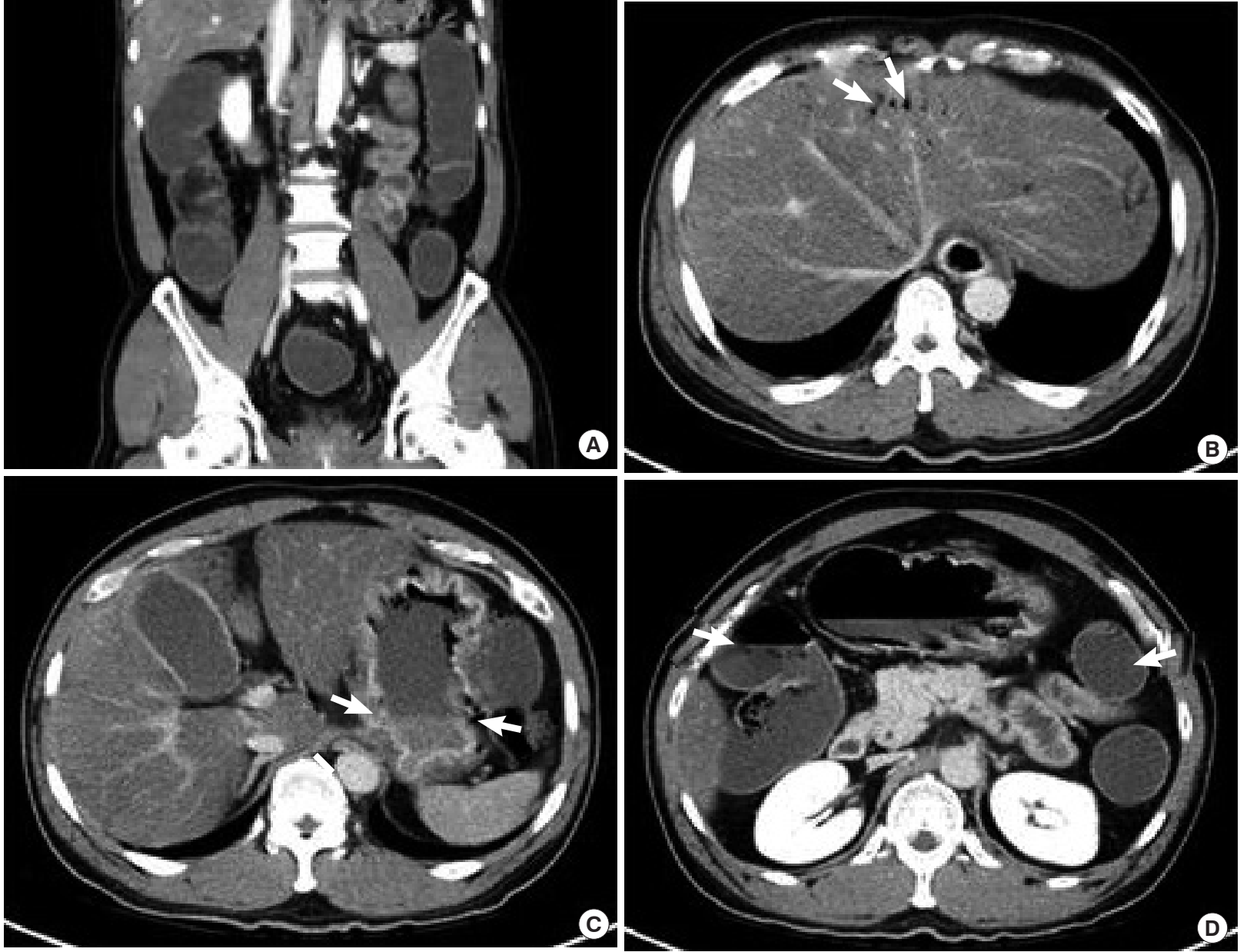

Table 2. Computed tomography grading system for caustic lesions

\begin{tabular}{ll}
\hline Grade & \multicolumn{1}{c}{ Features } \\
\hline 1 & No definite swelling of esophageal wall \\
2 & Edematous wall thickening without periesophageal soft tissue involvement \\
3 & Edematous wall thickening with periesophageal soft tissue infiltration plus a well-demarcated tissue interface \\
4 & $\begin{array}{c}\text { Edematous wall thickening with periesophageal soft tissue infiltration plus blurring of tissue interface or localized fluid collection around the esophagus or } \\
\text { descending aorta }\end{array}$
\end{tabular}

roid injections may augment the effects of endoscopic dilatation and reduce further fibrosis. ${ }^{14}$

MEKP is a potentially lethal industrial chemical; acute poisoning can occur after ingestion. Water bottles should not be used to store such toxic chemicals; all vessels containing dangerous liquids must be clearly marked. Furthermore, handlers of these uncommon toxic substances must be made aware of the potential toxicity, and safety measures must be implemented. 
MEKP causes severe corrosive injury to the upper gastrointestinal tract, as well as liver necrosis. Early endoscopy and CT can be used to identify perforation or hemorrhage in the gastrointestinal tract. Although upper gastrointestinal endoscopy is considered the mainstay of diagnosis, CT can be used to assess the need for emergency surgery. If perforation and severe continuous leakage of bowel contents does occur, surgery may be needed.

\section{CONFLICT OF INTEREST}

No potential conflict of interest relevant to this article was reported.

\section{REFERENCES}

1. American Conference of Governmental Industrial Hygienists. Documentation of the threshold limit value and biological exposure indices. 6th ed. Cincinnati, OH: American Conference of Governmental Industrial Hygienists; 1991.

2. Burger $L M$, Chandor SB. Fatal ingestion of plastic resin cataIyst. Arch Environ Health 1971;23:402-4.

3. Mittleman RE, Romig LA, Gressmann E. Suicide by ingestion of methyl ethyl ketone peroxide. J Forensic Sci 1986;31:31220.

4. Karhunen PJ, Ojanpera I, Lalu K, Vuori E. Peripheral zonal hepatic necrosis caused by accidental ingestion of methyl ethyl ketone peroxide. Hum Exp Toxicol 1990;9:197-200.

5. Wojdyla Z, Pach J, Kolodziej J. Fatal acute poisoning with ke- tonox. Arch Med Sad Krym 1979;29:199-205.

6. Litovitz TL, Schmitz BF, Bailey KM. 1989 annual report of the American Association of Poison Control Centers National Data Collection System. Am J Emerg Med 1990;8:394-442.

7. Moon SW, Lee SW, Choi SH, Hong YS. Gastric emphysema after methyl ethyl ketone peroxide ingestion. Clin Toxicol (Phila) 2010;48:90-1.

8. Subbalaxmi MV, Abkari S, Srinivasan VR, Krishnaprasad A. Methyl ethyl ketone peroxide ingestion: a rare cause of corrosive chemical poisoning. Natl Med J India 2010;23:150-1.

9. Bates $N$, Driver $C P$, Bianchi A. Methyl ethyl ketone peroxide ingestion: toxicity and outcome in a 6 -year-old child. Pediatrics 2001;108:473-6.

10. van Enckevort CC, Touw DJ, Vleming $\sqcup$. N-acetylcysteine and hemodialysis treatment of a severe case of methyl ethyl ketone peroxide intoxication. Clin Toxicol (Phila) 2008;46:74-8.

11. Ryu HH, Jeung KW, Lee BK, et al. Caustic injury: can CT grading system enable prediction of esophageal stricture? Clin Toxicol (Phila) 2010;48:137-42.

12. Kluger $Y$, Ishay $O B$, Sartelli $M$, et al. Caustic ingestion management: world society of emergency surgery preliminary survey of expert opinion. World J Emerg Surg 2015;10:48.

13. Bozdemir MN, Yildiz M, Seyhanli ES, Gurbuz S, Kilicaslan I, Karlidag T. Narrowing of airway caused by ingestion of methyl ethyl ketone peroxide. Hum Exp Toxicol 2011;30:2002-6.

14. Liyanage IK, Navinan MR, Pathirana AC, et al. A case of meth$y l$ ethyl ketone peroxide poisoning and a review of complications and their management. J Occup Med Toxicol 2015;10:26. 